\title{
Pre-Service Teachers' Motivation, Practices and Challenges in Using Mobile Learning to Enhance Teaching Activities in Tanzania
}

\author{
${ }^{1}$ Mohamed Muhibu Chuma, ${ }^{1,2}$ Jimmy Ezekiel Kihwele \\ ${ }^{1}$ Faculty of Education, Beijing Normal University, China \\ ${ }^{2}$ Faculty of Education, Mzumbe University, Tanzania \\ "Corresponding author: chumamohamed@gmail.com
}

\begin{abstract}
The study explored the motivation, practices and challenges of pre-service teachers in using mobile learning to enhance teaching activities. The ground of the study was the digital revolution of mobile electronic devices that penetrated to the population and therefore facilitated access to vast online resources as an alternative to traditional resources. A case study design with a mixed approach was employed, involving 110 pre-service teachers who pursued Bachelor of Education programs. Data collection methods involved in-depth interviews and questionnaires. The findings show that pre-service teachers were motivated to use mobile learning by individual factors and contextual situations. The use of mobile learning involved searching for teaching materials as well as answers to critical and challenging questions. Further, pre-service teachers learned new methods of managing students and lesson presentations through online lectures. Mobile learning nevertheless faced challenges of poor Internet connectivity in some areas and pre-service teachers' ability to determine whether the materials accessed came from valid and reliable sources. The study recommends that pre-services teachers should be trained in the skills of identifying reliable and valid sources of materials for effective teaching. There is also a need to educate pre-service teachers on how to access valid and reliable materials that are aligned to the curriculum and national education goals. Therefore, different sites should be made accessible to teachers to help them improve not only classroom teaching practices but also for learners' better performance.
\end{abstract}

Key words: Pre-service teachers, motivation, teaching practice, Mobile learning, teaching skills

\section{Introduction}

Modern technology, particularly which involves mobile devices, has supported teachers in the use of mobile learning in education context (Kearney \& Maher, 2019). As a result, pre-service teachers have integrated mobile learning to supplement inadequate materials in their schools. Mobile learning offers an opportunity to access vast materials and updated resources. The adequacy of modern teaching facilities and resources plays a great role in motivating pre-service teachers to like the profession and positively predicts the future of their careers (Okongo, Ngao, Rop, \& Nyongesa, 2015).

Teachers have been performing well in a working environment where there are enough materials and teaching aids to support their teaching (Likoko, Mutsotso, \& Nasongo, 2013). Likewise, students have developed and acquired desired competencies in a learning environment where there are adequate resources to assist their learning process. Therefore, meaningful learning requires not only adequate materials but also up-to-date and quality learning materials for both teachers and students. In Tanzania, the ratio of learning resources and materials is inadequate and the quality of those materials has been under scrutiny by various stakeholders (HakiElimu, 2016). The inadequacy of teaching and learning materials has pushed teachers to look for alternatives ways of accessing them such as the use of internet or purchasing books with their own money to ensure teaching and learning 
materials are enough to facilitate the learning process.

The Tanzanian government has invested to develop and improve the quality of the national education system. Since education is regarded as the central drive of national economic growth, the transformation of education starts with improving the teaching and learning from classroom levels. Integrating technology in teaching and learning is one of the important efforts taken to improve classroom practices. The government introduced two policies to enhance the use and integration of technology in education. The Information and Communication Technology Policy was introduced in 2003 (URT, 2003) and the Information and Communication Technology Policy for Basic Education was introduced in 2007 (URT, 2007).

While the ICT Policy of 2003 intended to raise awareness on the potentials of integrating technology in development activities, the ICT Policy of 2007 focused on transforming the education system with the integration of technology. Hennessy, Harrison and Wamakote (2010) pointed out that the established policy in modern technology in the education sector focused on providing quality services such as scientific, technological and skill based. The use of technology in education refers to the application of devices such as computers, projectors, mobiles phones, iPads and tablets to enhance communication and interaction among the resources for better and simplified classroom instructional processes (Ghavifekr \& Rosdy, 2015). The application of these technological devices promotes mobile learning for both teachers and students.

Mobile learning is defined is as the practice of using mobile electronic devices such as Smartphones, laptops, desktops and tablets for learning purpose where teachers and students can access materials and interact in different settings (Nickerson, Rapanta, \& Goby, 2017). Mobile learning is based on mobile device technologies in which teachers and students can communicate, share and post teaching and learning materials with Internet capabilities (AlTameemy, 2017). According to Walck, Cruikshank and Kalyango (2015) and Diliberto-Macaluso \& Hughes, (2016) mobile learning uses movable computing devices such as iPads, laptops, tablet PCs, PDAs and Smartphone that support, promote and allow effective teaching and learning. Moreover, mobile learning enables teaching and learning to be extended beyond the traditional classrooms.

The integration of technology like that of mobile learning enhances teachers' development of professional competencies through enabling learning interactions, construction of knowledge as well as storing and sharing information (Aldoobie, 2015; Balmeo et al., 2014; Buza \& Mula, 2017). The implementation of the policy in education involved efforts being made to enable schools to have access to ICT facilities. Factors like financial challenges, accessibility to internet connections, electricity in rural schools, qualified teachers to manage the facilities and poor maintenance in few available computers have pulled back the efforts to fully integrate technology in education (Cloete, 2017; Ghavifekr, Kunjappan, \& Ramasamy, 2016). According to Yusuf (2005), technology in education has impacted the quality and quantity of teaching, learning and research through its dynamic, interactive and potential to accelerate learning, deepen skills, facilitate teaching and engage students in learning.

The application of mobile learning relies greatly on the accessibility of ICT infrastructures (like Internet connectivity) and resources (supportive devices) to facilitate the teaching and learning process (Ghavifekr \& Rosdy, 2015). Despite the lack of ICT equipment in some schools, teachers are still expected to possess skills on how to practice the use of modern technology to enable the mobile learning (Kihoza, Zlotnikova, Bada, \& Kalegele, 2016). The application of mobile learning in classrooms demands teachers' skills and knowledge that is usually incorporated in teaching and learning. According to Ghavifekr et al. (2014), the use of technology should be included in the curriculum which provides a dynamic and proactive teaching and learning environment. Teachers are expected to be key players in integrating modern technology in classroom sessions.

There are efforts made to explore the formal use of technology in secondary schools with a purpose to support student learning and improve their performance (Barakabitze, Kitindi, Sanga, Kibirige, \& Makwinya, 2015; Kazoka \& William, 2016; Malero, Ismail, \& Manyilizu, 2015; Ngeze, 2017). The government is also encouraging schools to implement and introduce technology education in the curriculum (URT, 2003). Although very few secondary schools have managed to integrate 
technology in the teaching and learning, teachers have informally used their personal devices to access materials, to communicate and to share information that is intended to improve the teaching and learning process (Ndibalema, 2014; Ngeze, 2017).

The integration of mobile learning in pre-service teacher education has been reported in many studies (Sad \& Göktas, 2014; Kearney \& Maher, 2019; Adedoja \& Abimbade, 2016; Kim, Kim \& Choi, 2016). These studies have examined perceptions of pre-service teachers on mobile learning, how mobile learning influences the training of pre-service teachers and how mobile learning promotes professional learning networks among pre-service teachers. Little has been reported about motivation and practices especially in Tanzanian context. While during teaching practice, pre-service teachers have been observed using mobile learning facilities to prepare their lessons, the main objective of this study was to explore pre-service teacher's motivation, practices and challenges in using mobile learning to enhance their teaching activities. The study was guided by the following research questions:

1. What factors motivate pre-service teachers to use Mobile learning during teaching practices?

2. How do pre-service teachers use mobile learning to improve the teaching and learning process during the teaching practice?

3. What are the challenges facing pre-service teachers in using mobile learning?

\section{Literature Review}

In today's world, the use and practice of modern technology are inevitable in the education field. The rapid advancement of technology has led production of mobile devices that have been integrated in education to promote vast and diverse pedagogical methods in classroom settings (Hong \& Sullivan, 2013; Srisawasdi, Pondee, \& Bunterm, 2018 ). The use of mobile devices in the education field has been referred to as mobile learning which is a learning approach developed to enhance both teachers and students' performance and provide learning content for teaching and learning transactions (Ismail, Azizan, \& Gunasegaran, 2016). Previous studies revealed that the use of mobile learning in education has improved the transformation and facilitation of the teaching and learning processes. Garba, Byabazaire and Busthami (2015), for instance, pointed out that the use of mobile learning in classroom situations provides learners and teachers opportunities to quality teaching and learning methods that promote competence acquisition. Montrieux, Vanderlinde, Schellens and De Marez (2015) also show the essentiality of mobile learning in the field of education as it enhances learning approaches in classes that support constructivism to produce the knowledge responsible to facilitate innovation.

\section{Factors that Motivate Pre-service Teachers to Use Mobile Learning}

Several scholars like Ciampa (2017) and Courduff, Szapkiw and Wendt (2016) agreed that the use of mobile learning greatly facilitates teachers' knowledge development and changes beliefs in diagnosing students' needs and interests. Engaging students with content gives alternative means to understand and explain concepts as they have understood.

Anderson and Putman (2020) have mentioned confidence, experience and beliefs as factors associated with teachers integrating mobile learning to facilitate the teaching and learning process. Mwalongo (2011) adds that accessibility to technological devices and supportive infrastructures are the factors for teachers' integration of mobile learning in their teaching activities and engagement in professional development practices. Zogheib (2014) pointed out personal traits and motivational beliefs as the factors for using mobile learning as teachers consider that computer technology is useful to their professions and the students are motivated to use mobile learning in teaching and learning so as to improve learning outcomes. These factors that motivate teachers to use technological innovations such as mobile learning support the Unified Theory of Acceptance and Use of Technology [UTAUT] which asserts that, performance expectancy, effort expectancy, social influence and facilitating conditions determine teachers' behavior towards integrating technology (Radovan \& Kristl, 2017; Venkatesh, Morris, Davis, \& Davis, 2003).

Pre-service teachers use mobile learning to facilitate students' learning process in the classroom due to the fact that mobile learning helps to access materials and resources that can inspire and increase students' participation, developing 
language abilities, critical thinking, analyzing ideas and solving problems (Lahiri \& Moseley, 2018).

Understanding of pedagogy and perception of challenges on the use of such technologies are linked to the motivation in using mobile learning. Therefore, teachers should have the ability to develop and merge technological knowledge, content knowledge and pedagogical knowledge as explained in TPACK model (Koehler \& Mishra, 2009; Koehler, Mishra, Kereluik, Shin, \& Graham, 2014; Mishra \& Koehler, 2006). A study done by Liu et al. (2015) showed that the use of technology in classroom settings increases teacher-students active interaction that influences meaningful learning. In such a context, factors like topics and objectives of the study, classroom teaching and learning strategies and type of technology adopted should be considered in advance.

Cubukcuoglu (2013) discusses enabling factors for technology adoption in terms of schools and teachers. First, schools must provide facilities such as laptops and easy access to enabling teachers to integrate their teaching in the classroom with technology. The second is related to positive personal beliefs towards integrating technology in teaching although some teachers still prefer traditional teaching methods than technologyenhanced teaching approaches. Teachers who do not use technology enhanced pedagogy are less informed of its significance in teaching and learning.

Gilakjani (2013) further outlines key factors that contribute to teachers' use of mobile learning such as accessibility to personal laptops, tablets and smartphones, positive teacher beliefs and attitudes towards computer technology, access to professional development in computer technology, knowledge and experience. Like most teachers and students today have access to Smartphones, mobile learning has become reliable resources for teachers' use to instruct today's generation to stimulate students in the learning process and to improve students' performance (Kohnke, 2019).

According to Nickerson, Rapanta and Goby (2017), factors that support teachers to use of mobile learning in their instruction include lower cost of using mobile phones rather than computers, the gender equity factor and the simplicity of accessibility that is essential in online materials when compared with printed materials. Oz (2014) Points out that integrating mobile learning technology enhances engagement in learning activities, promotes interaction and creates a sense of community to both teachers and students.

\section{Integration of Mobile Learning in the Teaching Activities}

Studies have been conducted in several settings and results revealed that the use of technology in the classroom is fundamental for academic achievement as it changes classroom dynamics, encouraging student-centered learning (Claro et al., 2017; Dong et al., 2016; Ruggiero \& Mong, 2015). Educational researchers and practitioners have focused on studying how to enable pre- service teachers to teach with the support of mobile technology (Srisawasdi, Pondee, \& Bunterm, 2018).

Integration of technology in the classroom needs teacher preparation to improve abilities. When teachers integrate mobile learning, students not only become more engaged but also they begin to take more control over their own learning (Liu, 2016). While the integration of technology in the classroom encourages student's motivation, participation and creativity, evidence shows that pre-services teachers possess the ability of using technology to improve the integration into their teaching (Liu et al., 2015; Lahiri \& Moseley, 2018). Srisawasdi et al., (2018) postulate that to integrate mobile learning technology in the classroom setting, pre-service teachers need to consider pedagogy for specific subjects and must understand the relationship between pedagogy, content and technology to provide students with desired knowledge, skills and experience.

Ranasinghe and Leisher (2009) explained that the integration of technology as a teaching tool in the classroom helps to empower not only pre-service teachers but also student's basic skills and knowledge of critical thinking to be able to solve problems effectively. Admiraal et al. (2017) posit that the integration of technology in classroom settings has to interconnect with pedagogical and content knowledge in a flexible way to produce more student-centred learning conditions in class. The integration of mobile learning technology requires teachers to have strong content, pedagogical and technological knowledge to help students to think critically and to use the internet to interact with each other.

There are various obstacles in integrating mobile learning in the classroom. These include resources, 
training and support, teacher' confidence, beliefs about student learning and value of technology in the classroom. Existing literature pointed to hardware and software, teacher training and professional support as factors that encountered teachers in implementing technology effectively in the classroom (Ruggiero \& Mong, 2015).

Kelly (2015) proposed changes to overcome obstacles in successful integration of technology in the classroom; these include availability of professional teachers who are knowledgeable in mobile learning to implement a new systematic model that integrates mobile learning to enhance the instructional strategies in the classroom. The skills, knowledge and experience should not only be on how to use electronic devices but how to integrate them in pedagogy to assist learners in constructing new knowledge in a simplified way.

Nickerson, Rapanta and Goby (2017) assert that integrating mobile learning into pedagogy is significant for supporting, motivating and improving students' attitudes toward learning in the classroom. Integration of mobile learning in the classroom further helps to encourage relationships between teacher and student (Walck, Cruikshank, \& Kalyango, 2015). Mobile learning can be integrated in traditional classroom as student's access printed materials and internet services to interact with instructors in order to explore learning skills and outcomes (Geng, 2013).

\section{Challenges Facing Pre-service Teachers in Using Mobile Learning}

Despite the growth of prevalence of mobile learning in schools, pre-services teachers encounter challenges during their teaching practices to facilitate the learning process. Studies conducted shows that pre-service teachers find it difficult to utilize mobile devices due to issues such as technical knowledge, skills, experiences and the availability of internet to access design material for distribution (Billingsley \& Scheuermann, 2014; Wai $\&$ Chen, 2015). These challenges hinder effective integration of mobile learning in elevating preservice teachers' activities that can help them develop in the teaching career.

Another challenge facing pre-service teachers is the presence of digital divide that requires them to develop necessary knowledge and skills on how to link accessed materials with the curricula requirements. Digital divide is "an inequality in access, distribution, and use of information and communication technologies between two or more populations" (Acılar, 2011). It is a gap between those with and those without access to technology. In this respect, pre-service teachers have also been divided in the sense that there are those with access and skills to harness the benefits of mobile learning and those who struggle to reach the target (Aubusson, Schuck, \& Burden, 2009).

\section{Research Methodology}

This section presents the methodology that guided the study.

\section{Research Design}

The study adopted a case study design with a mixedmethod approach to obtain information from respondents about motivation, practices towards using mobile learning to improve classroom teaching activities and challenges faced. First, the study employed qualitative approach that involved in-depth interviews with respondents. Then 21 questionnaire items were developed from the themes that emerged from the analysis. These items were distributed to a larger group of respondents to establish their responses. The presentation of the data therefore started with qualitative analysis with direct quotations from respondents followed by a summary of quantitative data presented in tables.

\section{Participants}

Respondents were pre-service teachers pursuing Bachelor of Education programs in the Department of Education Foundations and Teaching Management at Mzumbe University. Three programs included were the Bachelor of Education in Languages and Management (BED-LM), Bachelor of Education in Commerce and Accountancy (BEDCA) and Bachelor of Education in Economics and Mathematics (BED-EM). A total of 110 respondents were involved as respondents. Among them, 13 respondents were invited for interview sessions. Pre-service teachers from these programs attended a teaching practice period of 8 weeks at the end of second semester in their first and second years of study in the 2018/2019 academic year. After completing their teaching practice, the researchers asked for their willingness to share their experience regarding using mobile learning to enhance their teaching activities.

\section{Data Collection Method}

Data was collected through in-depth interviews that involved 13 pre-service teachers. These 13 pre- 
service teachers were obtained through purposive and snowballing sampling techniques. The respondents who were selected purposively are those who frequently used their mobile phones and laptops to share new materials, links and videos as teaching aids. After obtaining the first few respondents, they were requested to identify other respondents who they were sure that they had the same qualification. These respondents were believed to have access to mobile learning and through sharing they influenced others. In this regard, it was believed that they could provide useful information on the motivation and practices towards using mobile learning to improve classroom teaching activities. A questionnaire with 21 items was constructed based on the findings obtained from the interviews and shared through WhatsApp groups and Facebook pages of the students from the department of education. The items included gender, type of school they taught during teaching practice, level they taught, whether they used mobile learning and type of devices they used. The instrument also included items that were specific on the practises of using mobile learning, factors that motivated them and challenges they encountered in the process of using mobile learning technology.

\section{Statistical Treatment of Data}

The analysis of data involved two parts. The closedended items were analysed and presented in percentages and figures. The open-ended items and interview data were analysed through coding and categorizing the emerging themes according to specific research questions. Also, quotations from the open-ended items and interview were used to support the arguments and claims made by respondents. The analysis helped to establish factors that motivated pre-service teachers to use mobile learning to enhance their teaching practices and explained how they used mobile learning in their context.

\section{Ethical Consideration}

Participants were informed about the purpose of the study prior to participating in providing information through the filling in of the questionnaires and engagement into the interviews. Oral consent was obtained for the respondents who participated. From the interview, respondents were named "Respondent 1" to "Respondent 13" to ensure anonymity of their identities. Confidentiality of the information gathered from the respondents was ensured and the information was used for the purpose of study only. All gathered information were confidential and were used for the purpose of this study only.

\section{Findings and Discussion}

The findings are organized according to the research questions that guided the study. Tables are used to illustrate findings of the study.

Table 1: Distribution of demographic aspects

\begin{tabular}{|c|c|c|c|c|c|}
\hline No & \multicolumn{2}{|c|}{ Demographic aspects } & \multirow{2}{*}{$\begin{array}{c}\# \\
82\end{array}$} & \multirow{2}{*}{$\begin{array}{c}\% \\
74.55\end{array}$} & \multirow{2}{*}{$\begin{array}{c}\text { Total } \\
110(100 \%)\end{array}$} \\
\hline \multirow{2}{*}{1} & Gender & Male & & & \\
\hline & & Female & 28 & 25.45 & \\
\hline \multirow[t]{2}{*}{2} & Type of school by ownership & Public & 92 & 83.64 & $110(100 \%)$ \\
\hline & & Private & 18 & 16.36 & \\
\hline \multirow[t]{3}{*}{3} & Levels of teaching & Ordinary level & 78 & 71 & $110(100 \%)$ \\
\hline & & Advanced level & 10 & 9.1 & \\
\hline & & Both levels & 22 & 20 & \\
\hline \multirow[t]{2}{*}{4} & Have you ever used mobile & Yes & 103 & 94.83 & $110(100 \%)$ \\
\hline & learning? & No & 7 & 5.17 & \\
\hline \multirow[t]{2}{*}{5} & Devices used & Smart phones & 54 & 93.64 & $110(100 \%)$ \\
\hline & & Laptop & 3 & 6.36 & \\
\hline
\end{tabular}

\section{Demographic information}

As reflected in Table 1, male pre-service teachers appear to be the best users of mobile learning than females. The reason might be the gender imbalance in the bachelor degree program that was involved in the study. Public schools accept a larger number of pre-service teachers than private schools which have limited positions for some subjects only. This might explain the high percent of pre-service teachers to come from public schools. In many schools, pre-service teachers are regarded as inexperienced trainees; therefore, they are assigned to teach lower levels. Few who were teaching in advanced levels had prior teaching experience or were teaching mathematics, one of the subjects that has a small number of teachers in schools. 
These pre-service teachers had access to devices like smartphones and laptops because they are more common in local contexts than tablets and iPads. In this study, 95\% of pre-service teachers admitted to have used their devices (smart phones or laptop) to access materials, to find solutions to challenging questions and to communicate with colleagues concerning teaching activities (both content and pedagogy). Also, many pre-service teachers joined groups in social media like WhatsApp, Facebook and telegram which are based on specific subjects. This might explain why a large number of pre-service teachers had ever used mobile learning.

Research Question 1: What factors motivate preservice teachers to use Mobile learning during teaching practices?

In response to the first research question, several factors are associated with pre-services teachers' use of mobile learning. Some pre- services teachers were pushed to use mobile learning due to lack of enough and appropriate traditional materials for teaching and learning. Many schools are said to have few books and in many cases several copies of the same book. The situation becomes challenging as pre-services teachers require additional materials in vain and the quick option is integrating mobile learning as a solution as evidenced by the following quotations from pre-services teachers.

"I used my mobile phone to search variety of teaching materials from different sources other than book" (Respondent 5, 2020). "I was pushed to search using my laptop because of inadequate teaching and learning resources at the school where I was teaching" (Respondent 1, 2020).

In addition to accessing adequate teaching and learning materials, some pre-services teachers used mobile learning because it provided quick answers to problems emanating from classroom discussions. One respondent replied that; - "I like to frequently search through mobile because it provides answers right away, making it a reliable reference for me in simplifying teaching" (Respondent 9, 2020). Another pre-service teacher added that; - "[Mobile learning] is the fastest and accurate way of getting information or learning materials instead of using more time to find it in library shelves and sometimes it can be difficult to get what you expect because of scarce materials available in the library" (Respondent 5, 2020).
In order to activate students' active participation in the learning process, pre-service teachers used mobile learning to display actual cases as part of linking what was being taught to real situations in life. This is evidenced by a quotation from one respondent that, "Through using a laptop, I was able to demonstrate the concept effectively to the students and to link it to their living environment. This promoted active learning in class" (Respondent 10, 2020). This finding proves how pre-services teachers improved their teaching practices to deliver the lesson well in their classes through technology.

Some pre-service teachers were motivated to integrate mobile learning in their teaching activities due to an inner desire that they like to improve their professional knowledge before their students. Teachers feel proud when they manage well students in the classroom and deliver good lessons. One response registered says; - "I like to use mobile learning because it helps me to access extra material out of the syllabus which promotes extra understanding and improves my pedagogical skills and knowledge" (Respondent 8, 2020).

The accessibility to internet connections through free $\mathrm{Wi}-\mathrm{Fi}$ in school settings also motivated preservices teachers to use Smartphones and laptops as means of mobile learning. Pre- services teachers were aware that through mobile learning, they can access rich, vast and diverse resources in various websites. As a result, when they were exposed to the environment with free internet connection they never hesitated to use their Smartphone and laptops for learning and improving their content and pedagogical competencies. To support the point, one respondent said; - "The main factor is about the environment found in the school, the availability of the network" (Respondent 12, 2020).

The synthesis of the findings from the interview was developed into questionnaires and it was filled in with a larger group of the respondents as reflected in table 2. From the table, respondents agreed to have used mobile learning due to adequate materials accessed, provision of answers to questions and the fact that it provides actual case studies for lessons. Also, another motivating factor was pre-service teachers' inner desire to use mobile learning and accessibility to internet for elevating their classroom teaching practice. 
Table 2: Responses on the factors motivating Pre-service teachers to use mobile learning

\begin{tabular}{|c|c|c|c|c|c|c|}
\hline No & Items in the Questionnaire & SD & D & $\mathbf{N}$ & A & SA \\
\hline 1 & $\begin{array}{l}\text { I use mobile learning due to lack of enough and } \\
\text { appropriate materials for teaching and learning in } \\
\text { schools }\end{array}$ & $\begin{array}{c}4 \\
(3.6 \%)\end{array}$ & $\begin{array}{c}7 \\
(6.4 \%)\end{array}$ & $\begin{array}{c}8 \\
(7.3 \%)\end{array}$ & $\begin{array}{c}42 \\
(38.2 \%)\end{array}$ & $\begin{array}{c}49 \\
(44.5 \% \\
\quad)\end{array}$ \\
\hline 2 & $\begin{array}{l}\text { I use mobile learning because it provided quick answers } \\
\text { to problems emanating from classroom discussions }\end{array}$ & $\begin{array}{l}2 \\
(1.8 \%)\end{array}$ & $\begin{array}{l}8 \\
(7.3 \%)\end{array}$ & $\begin{array}{c}18 \\
(16.5 \%)\end{array}$ & $\begin{array}{c}38 \\
(34.9)\end{array}$ & $\begin{array}{c}43 \\
(39.4)\end{array}$ \\
\hline 3 & $\begin{array}{l}\text { I use mobile learning to display actual cases like videos, } \\
\text { pictures etc. as part of linking what was being taught to } \\
\text { real situations in life }\end{array}$ & $\begin{array}{c}8 \\
(7.3 \%)\end{array}$ & $\begin{array}{l}6 \\
(5.5 \%)\end{array}$ & $\begin{array}{c}17 \\
(15.6 \%)\end{array}$ & $\begin{array}{c}32 \\
(29.4 \%)\end{array}$ & $\begin{array}{l}46 \\
(42.2 \% \\
\quad)\end{array}$ \\
\hline 4 & $\begin{array}{l}\text { I am motivated to integrate mobile learning in teaching } \\
\text { activities due to inner desire that I like to improve the } \\
\text { professional knowledge before my students }\end{array}$ & $\begin{array}{c}4 \\
(3.6 \%)\end{array}$ & $\begin{array}{c}7 \\
(6.4 \%)\end{array}$ & $\begin{array}{c}20 \\
(18.2 \%)\end{array}$ & $\begin{array}{c}41 \\
(37.3 \%)\end{array}$ & $\begin{array}{c}38 \\
(34.5)\end{array}$ \\
\hline 5 & $\begin{array}{l}\text { The accessibility of internet connections through free Wi- } \\
\mathrm{Fi} \text { in school setting also motivates me to use Smartphone } \\
\text { and laptops to as means of mobile learning }\end{array}$ & $\begin{array}{c}9 \\
(8.2 \%)\end{array}$ & $\begin{array}{c}12 \\
(10.9 \%)\end{array}$ & $\begin{array}{c}12 \\
(10.9 \%)\end{array}$ & $\begin{array}{c}29 \\
(26.4 \%)\end{array}$ & $\begin{array}{c}48 \\
(43.6)\end{array}$ \\
\hline
\end{tabular}

Research Question 2: How do pre-service teachers use mobile learning to improve the teaching and learning process during the teaching practice?

In response to the second research question, preservice teachers' use of mobile learning involved accessing various sites where they found relevant materials of their desire. They particularly mentioned the specific websites and search engines they frequently visited. The results show that search engines frequently visited include Google, opera mini, Amazon and Quora. Websites that were frequently visited are Encyclopaedia, Phoenix browser, academia, YouTube, Facebook and local visited websites such as Jamii forum, THL, Maktaba. Using the search engines to visit various Webpages was easier for pre-service teachers to access important information about the lessons they prepared to teach and how well they could teach.

The responses from the pre-service teachers concerning how they used mobile learning to elevate their teaching practices reveals that they used mobile learning to search for materials to facilitate the teaching and learning processes. The specific issues that are accessed through mobile learning include teaching and learning materials, supplementary readings and learning different techniques for assessing and evaluating students' achievement of expected learning competence. This shows how the pre-service teachers integrated the technology as far as the teaching and learning process is concerned. One respondent said "I used to search different materials that helped me to get different knowledge" (Respondent 3, 2020). This implies that mobile learning is beneficial to preservice teachers in broadening and strengthening their content and pedagogical knowledge.
The findings regarding how mobile learning helped pre-service teachers to improve classroom practices revealed that pre-service teachers developed new skills in managing both students in the classroom and lessons that were being delivered. Managing students in the classroom involved learning techniques that ensure no student lags behind during the learning process. New teaching and learning methods were learnt to give teachers wider options of mobbing on with all students towards achieving the expected learning outcomes. To support this finding, one pre-service teacher said; -

Teaching students with different abilities and behaviors is very challenging; if you [a teacher] are not careful you will engage only those active learners in the learning process. Therefore, I have been searching for techniques and methods that will engage all learners in my class (Respondent 11, 2020).

Mobile learning enabled proper management of lessons like accessing varieties of high quality teaching and learning materials. Also, mobile learning facilitated communication and interaction with fellow teachers and experts in specific areas of specialization. Some of the responses from preservice teachers include; - "It helps to get learning and teaching material, provides me with new techniques in my teaching, experience and knowledge on how to use technology" (Respondent 3, 2020). Another pre-service teacher responded that; - "It helps me a lot especially where I need questions so I used my mobile phone to communicate with other teachers for assistance and solution" (Respondent 8, 2020). 
Accessing vast resources like teaching and learning materials and more appropriate and vivid teaching aids involving audio-visual materials not only helps teachers to improve their teaching practices, but helps learners to learn better. Pre-service teachers watched online videos on how to manage classrooms. Also, some teachers downloaded and showed students the online lecturers related to specific concepts they were discussing in the classroom.

Mobile learning also offered pre-service teachers an opportunity to quickly search for answers and/or current data for some specific subjects. Some preservice teachers were looking for derivation of formulas in simple elaborated ways that are easily understood by learners. The claim is backed by the following quotation; - "I was searching for a mathematical formula, how to derive and apply in solving relevant problems". Another teacher used mobile learning to find a simple definition of concepts for learners to easily digest the content being delivered in specific lessons. This respondent said; - "I used mobile learning to search the meaning of difficult vocabularies, this helped to understand simple words and explain complex concepts" (Respondent 7, 2020).

The findings show that mobile learning facilities are important for pre-service teachers and were frequently used during the teaching practice. Mobile learning provides new experience and expands professional knowledge through communicating with colleagues and accessing appropriate material for students, improving the methodology of teaching.

Table 3 provides responses from the questionnaire that was developed from the analysis of interviews conducted. As seen in the table, the majority of respondents agreed that they engaged in practices that integrated mobile learning in teaching activities. For instance, they agreed that they used mobile leaning to access various sites like Google, Opera Mini, Amazon to access materials.

Table 3: Responses showing the practices of using mobile learning

\begin{tabular}{|c|c|c|c|c|c|c|}
\hline No & Items in the Questionnaire & SD & D & $\mathbf{N}$ & A & SA \\
\hline 1 & $\begin{array}{l}\text { I use mobile learning to access various sites like Google, } \\
\text { opera mini, Amazon and Quora where I can find relevant } \\
\text { materials for teaching my students }\end{array}$ & $\begin{array}{c}8 \\
(7.3 \%)\end{array}$ & $\begin{array}{c}5 \\
(4.6 \%)\end{array}$ & $\begin{array}{c}4 \\
(3.7 \%)\end{array}$ & $\begin{array}{c}40 \\
(36.7 \%)\end{array}$ & $\begin{array}{c}52 \\
(47.7 \%)\end{array}$ \\
\hline 2 & $\begin{array}{l}\text { I use mobile learning to search materials or } \\
\text { supplementary readings to facilitate teaching and } \\
\text { learning process }\end{array}$ & $\begin{array}{c}2 \\
(1.8 \%)\end{array}$ & $\begin{array}{c}5 \\
(4.5 \%)\end{array}$ & $\begin{array}{c}11 \\
(10 \%)\end{array}$ & $\begin{array}{c}41 \\
(37.3 \%)\end{array}$ & $\begin{array}{c}51 \\
(46.4 \%)\end{array}$ \\
\hline 3 & $\begin{array}{l}\text { Mobile learning helps to improve classroom practices } \\
\text { and developed new skills of managing both students in } \\
\text { the classroom and lessons that were being delivered }\end{array}$ & $\begin{array}{c}2 \\
(1.9 \%)\end{array}$ & $\begin{array}{c}10 \\
(9.3 \%)\end{array}$ & $\begin{array}{c}15 \\
(13.9 \%)\end{array}$ & $\begin{array}{c}49 \\
(45.4 \%)\end{array}$ & $\begin{array}{c}32 \\
(29.6 \%)\end{array}$ \\
\hline 4 & $\begin{array}{l}\text { Mobile learning enables proper management of lessons } \\
\text { like accessing varieties of high quality teaching and } \\
\text { learning materials and teaching aids }\end{array}$ & $\begin{array}{c}4 \\
(3.7 \%)\end{array}$ & $\begin{array}{c}9 \\
(8.3 \%)\end{array}$ & $\begin{array}{c}13 \\
(12 \%)\end{array}$ & $\begin{array}{c}43 \\
(39.8 \%)\end{array}$ & $\begin{array}{c}39 \\
(36.1 \%)\end{array}$ \\
\hline 5 & $\begin{array}{l}\text { Mobile learning also offers an opportunity to quickly } \\
\text { search for answers and/or current and correct data for } \\
\text { some specific subjects }\end{array}$ & $\begin{array}{c}5 \\
(4.5 \%)\end{array}$ & $\begin{array}{c}2 \\
(1.8 \%)\end{array}$ & $\begin{array}{c}11 \\
(10 \%)\end{array}$ & $\begin{array}{c}52 \\
(47.3 \%)\end{array}$ & $\begin{array}{c}40 \\
(36.4 \%)\end{array}$ \\
\hline 6 & $\begin{array}{l}\text { Mobile learning is important for pre-service teachers and } \\
\text { is frequently being used during teaching practice }\end{array}$ & $\begin{array}{c}6 \\
(5.5 \%)\end{array}$ & $\begin{array}{c}13 \\
(11.8 \%)\end{array}$ & $\begin{array}{c}16 \\
(14.5 \%)\end{array}$ & $\begin{array}{c}32 \\
(29.1 \%)\end{array}$ & $\begin{array}{c}43 \\
(39.1 \%)\end{array}$ \\
\hline
\end{tabular}

They also agreed that they use mobile learning to search materials or supplementary readings to facilitate the teaching and learning process and that mobile learning helps to improve classroom practices and developed new skills of managing both students in the classroom and lessons that were being delivered. Furthermore, they agreed that mobile learning enables proper management of lessons like accessing varieties of high quality teaching and learning materials and teaching aids, that mobile learning offers an opportunity to quickly search for answers and/or current and correct data for some specific subjects and that mobile learning is important for pre-service teachers and is frequently being used during teaching practice. The few respondents who disagreed with the statements in the questionnaire might be the ones that faced challenges in accessing internet services or lacked skills to access materials and integrate mobile learning in their teaching practices.

82 East African Journal of Education and Social Sciences (EAJESS) 1(2)74-89 
Research Question 3: What are the challenges facing pre-service teachers in using mobile learning?

On the other hand, pre-service teachers faced challenges in the process of using mobile learning in accessing teaching and learning materials. The primary challenge was limited access to some sites where they believed there were quality materials. One response states that; - "There are charges of materials for some page, as you are required to buy the file you want to download or search for alternative ways" (Respondent 8, 2020). In that case, the small part of materials or the page is seen and the large part hidden for subscribers only. As a result, teachers who informally use mobile learning stumble and give up or visits pages with less trusted sources.

Table 4: Responses on Challenges Facing Pre-service Teachers in Using Mobile Learning

\begin{tabular}{|c|c|c|c|c|c|c|}
\hline & $\begin{array}{l}\text { The challenges facing pre-service teachers in using } \\
\text { mobile learning }\end{array}$ & SD & D & $\mathbf{N}$ & A & SA \\
\hline 1 & $\begin{array}{l}\text { The primary challenge of using mobile learning is } \\
\text { limited access to some sites where I can obtain } \\
\text { adequate and quality materials }\end{array}$ & $\begin{array}{c}6 \\
(5.5 \%)\end{array}$ & $8(7.3 \%)$ & $\begin{array}{c}12 \\
(11 \%)\end{array}$ & $\begin{array}{c}37 \\
(33.9 \%)\end{array}$ & $\begin{array}{c}46 \\
(42.2 \%)\end{array}$ \\
\hline 2 & $\begin{array}{l}\text { Poor internet connection is a common challenge for } \\
\text { effectively using mobile learning }\end{array}$ & $\begin{array}{c}1 \\
(0.9 \%)\end{array}$ & $4(3.7 \%)$ & $\begin{array}{c}12 \\
(11.1 \%)\end{array}$ & $\begin{array}{c}38 \\
(35.2 \%)\end{array}$ & $\begin{array}{c}53 \\
(49.1 \%)\end{array}$ \\
\hline 3 & $\begin{array}{l}\text { Availability of many and diverse materials from the } \\
\text { visited sites challenged pre-service teachers in deciding } \\
\text { the right materials to use and correct answers out of } \\
\text { many options available }\end{array}$ & $\begin{array}{c}9 \\
(8.3 \%)\end{array}$ & $\begin{array}{c}15 \\
(13.9 \%)\end{array}$ & $\begin{array}{c}18 \\
(17.7 \%)\end{array}$ & $\begin{array}{c}32 \\
(29.6 \%)\end{array}$ & $\begin{array}{c}34 \\
(31.5 \%)\end{array}$ \\
\hline 4 & $\begin{array}{l}\text { I have the skills to enable me select appropriate } \\
\text { materials that fits the level of students I teach }\end{array}$ & $\begin{array}{c}4 \\
(3.7 \%)\end{array}$ & 7 (6.4\%) & $\begin{array}{c}24 \\
(22 \%)\end{array}$ & $\begin{array}{c}34 \\
(31.2 \%)\end{array}$ & $\begin{array}{c}40 \\
(36.7 \%)\end{array}$ \\
\hline 5 & $\begin{array}{l}\text { I have skills and knowledge of searching and selecting } \\
\text { appropriate materials that are aligns with the syllabus }\end{array}$ & $\begin{array}{c}3 \\
(2.8 \%)\end{array}$ & $\begin{array}{c}14 \\
(12.8 \%)\end{array}$ & $\begin{array}{c}10 \\
(9.2 \%)\end{array}$ & $\begin{array}{c}33 \\
(30.3 \%)\end{array}$ & $\begin{array}{c}49 \\
(45 \%)\end{array}$ \\
\hline
\end{tabular}

Also, poor internet connection was a common challenge as a number of pre-service teachers failed to effectively use mobile learning due to such a limitation. The response from one pre-service teacher was; - "Problems with the internet in some areas, hence it requires you [a teacher] to spend more time in certain places in order to access the internet. So the area where the school was situated limited the use of mobile learning" (Respondent 7, 2020). The explained situation proves that preservice teachers may not manage to fully integrate mobile learning to elevate teaching practices.

Availability of vast and diverse materials from the visited sites challenged pre-service teachers in deciding the right materials to use and correct answers out of many options available. When preservice teachers' lack ability to understand useful materials that fit the cognitive level of their students, mobile learning becomes a threat for students' learning. One respondent narrates that; "Too many scholars have written many issues concerning the same issue and are contrary to each other. This challenges me specially to understand the correct and incorrect materials based on the level of my learners as well as curriculum requirement" (Respondent 2, 2020).

Although respondents agreed that they integrated mobile learning in their teaching activities, they also faced some challenges that affected the rate of integration. Limited access to some websites, poor or unavailability of internet connections and limited skills on how to select appropriate materials for learners were challenges they encountered.

\section{Discussion}

The study explored pre-service teacher's motivation and practices in using mobile learning to enhance their teaching activities during the teaching practice. Mobile learning plays a significant role in teaching and learning like facilitating accessibility to materials, learning new methods of teaching as well as assessing and managing learners. The main practices related to mobile learning that pre-service teachers integrated in their teaching activities were to search for materials to supplement the scarce 
materials available in schools for smooth teaching and learning. Second, pre-service teachers used mobile learning to search for answers to difficult questions that came from classroom discussions or was shared through social media groups. Thirdly, pre-service teachers used mobile learning to watch online lectures on how other teachers teach and manage the learning process in their classes so that they can emulate the same in their classes. Lastly, pre-service teachers searched for vivid teaching aids to assist learners in the process of knowledge construction.

The main practices related to the use of mobile learning elevated teachers' confidence in teaching and improved pedagogical skills through learning varieties of methods and strategies of managing diverse classrooms which resonates to studies conducted by Claro et al. (2017) and Dong et al. (2016). Also content knowledge of pre-service teachers improved as they learnt from online sources and interacted with their colleagues.

It is evident that the motivation for pre-service teachers to use mobile learning was primarily caused by personal and contextual factors. Personal factors for using the mobile learning include finding answers to challenging questions, the need to improve class management and lesson presentation skills as well as understanding simple ways of making learners grasp the concepts being taught. These personal factors reflect the need to develop confidence and expertise during classroom teaching which is similar to findings reported by Anderson and Putman (2020). The social networks such as WhatsApp, Facebook and YouTube were accessed and which gave pre-services teachers an opportunity to interact with other teachers to learn new skills and observe how other teachers managed teaching and learning activities.

The contextual factors associated with motivating pre-services teachers to integrate mobile learning include the inadequacy of teaching and learning materials as reported by Mwalongo (2011). Effective learning requires a variety of materials reflecting different angles and perspectives. The motives behind using mobile learning were to ensure learners have diverse materials not homogenous to spark the broader thinking. Regardless of the reported benefits, the use of mobile learning was informal and self-initiatives of pre-services teachers towards elevating their professional practices. The challenges they faced include lack of reliable internet connection. Also, another obstacle that challenged pre-service teachers was the requirement of subscription to access some of the useful materials. This denied them an opportunity to better enhance their teaching practices and improve their teaching skills.

\section{Conclusions and Recommendations}

After presentation of results, this section gives conclusions and recommendations of the study.

\section{Conclusions of the Study}

The study concludes that in the age of digital revolution, mobile learning is inevitable for preservice teachers in facilitating the teaching and learning processes and elevating their professional competencies. There are various motives that push pre-service teachers to integrate mobile learning including personal factors and contextual factors. There are also intrinsic and extrinsic factors that motivates pre-service teachers to integrate mobile learning to improve their teaching practices. Preservice teachers' efforts to use mobile learning was challenged by inadequate facilities and limited skills. It is also concluded that mobile learning improves both pre-service teachers' content knowledge and pedagogical skills. The study therefore provides insights on commitments made by individual teachers in schools; hence, these efforts should be commended and supported.

\section{Recommendations of the Study}

The study recommends that education institutions should establish mechanisms to encourage and guide the use of mobile learning. Individual and contextual motivation should critically be sustained to allow teachers learn to be aligned with authorized syllabus in schools. The mechanism should sustain mobile learning practices through making it formal. Institutions have to provide internet connection and a list of reliable sites for each subject. The informal and self-initiated efforts of pre-service teachers should be encouraged and supported since the impact is not only to teaching practices but also to learners' achievement of expected learning outcomes.

The authenticity of sites visited, sources of material obtained and how the materials align with the syllabus and education objectives should be the issue of concern. Pre-services teachers should be trained in the skills of identifying reliable and valid sources of materials. Also efforts should be made to subscribe to those sites that are useful to both 
teachers and learners for easy access. There is also a need to educate pre-service teachers on how to access valid and reliable materials that are aligned to the curriculum and national education goals. Therefore, different sites should be made accessible to teachers to help them improve not only classroom teaching practices but also for learners' better performance. Also other varieties of teaching and learning materials of specific subjects should be deployed to schools.

\section{Reference}

Acilar, A. (2011). Exploring the Aspects of Digital Divide in a Developing Country. Ilssues in Nforming Science and Information Technology, 8, 231-244.

Adedoja, G., \& Abimbade, O. (2016). Influence of Mobile Learning Training on Pre-service Social Studies Teachers' Technology and Mobile Phone Self-Efficacies. Journal of Education and Practice, 7(2), 74-79. Retrieved from www.iiste.org

Admiraal, W., Vugt, F. Van, Kranenburg, F., Koster, B., Smit, B., Weijers, S., \& Lockhorst, D. (2017). Preparing pre-service teachers to integrate technology into $\mathrm{K}-12$ instruction : evaluation of a technology-infused approach. Technology, Pedagogy and Education, 26(1), 105-120. https://doi.org/10.1080/1475939X.2016.11 63283

Aldoobie, N. (2015). Technology integration and learning theory. American International Journal of Contemporary Research, 5(6), 114-118.

Al-Tameemy, F. (2017). Mobile Phones for Teaching and Learning. Journal of Educational Technology Systems, 45(3), 436-451. https://doi.org/10.1177/004723951665975 4

Anderson, S. E., \& Putman, R. S. (2020). Special Education Teachers' Experience, Confidence, Beliefs, and Knowledge About Integrating Technology. Journal of Special Education Technology, 35(1), 37-50. https://doi.org/10.1177/0162643419836409
Mobile learning for teacher professional learning: benefits, obstacles and issues. Alt-J, 17(3),

233-247. https://doi.org/10.1080/09687760903247641

Balmeo, M. L., Nimo, E. M. A., Pagal, A. M., Puga, S. C., ArisDafQuiño, \& Sanwen, J. L. (2014). Integrating Technology in Teaching Students with Special Learning Needs in the SPED Schools in Baguio City. IAFOR Journal of Education, 2(2), 149-178. https://doi.org/10.22492/ije.2.2.05

Barakabitze, A. A., Kitindi, E. J., Sanga, C., Kibirige, G., \& Makwinya, N. (2015). Exploring Students' Skills and Attitudes on Effective Use of ICTs: Case Study of Selected Tanzanian Public Secondary Schools. Universal Journal of Educational Research, 3(6), 407-425. https://doi.org/10.13189/ujer.2015.030609

Billingsley, G. M., \& Scheuermann, B. K. (2014). Using Virtual Technology to Enhance Field Experiences for Pre-Service Special EducationTeachers. https://doi.org/10.1177/088840641453041 3

Buza, K., \& Mula, Mf. (2017). The role of the Teachers in the integration of ICT in Teaching in Secondary Low Education. European Journal of Social Sciences Education and Research, 10(2), 240. https://doi.org/10.26417/ejser.v10i2.p240247

Ciampa, K. (2017). Building bridges between technology and content literacy in special education: Lessons learned from special educators' use of integrated technology and perceived benefits for students. Literacy Research and Instruction, 56, 85-113. doi:10.1080/19388071.2017.1280863

Claro, M., Nussbaum, M., López, X., Contardo, V., Claro, M., Nussbaum, M., ... Contardo, V. (2017). Differences in Views of School Principals and Teachers regarding Technology Integration. Journal of Educational Technology \& Society, 20(3), 42-53.

Aubusson, P., Schuck, S., \& Burden, K. (2009). 
Cloete, A. L. (2017). Technology and education: Challenges and opportunities. HTS Teologiese Studies / Theological Studies, 73(4), $1-7$. https://doi.org/10.4102/hts.v73i4.4589

Courduff, J., Szapkiw, A., \& Wendt, J. L. (2016). Grounded in what works: Exemplary practice in special education teachers' technology integration. Journal of Special Education Technology, 31, 26-38. doi:10.1177/0162643416633333

Cubukcuoglu, B. (2013). Factors enabling the use of technology in subject teaching. International Journal of Education and Development using Information and Communication Technology 9(3), 50-60

Diliberto-Macaluso, K., \& Hughes, A. (2016). The Use of Mobile Apps to Enhance Student Learning in Introduction to Psychology. The teaching of Psychology, 43(1), 48-52. https://doi.org/10.1177/0098628315620880

Dong, Y., Chai, C. S., Sang, G., Hwee, J., Koh, L., Dong, Y., ... Tsai, C. (2015). Exploring the Profiles and Interplays of Pre-service and Inservice Teachers ' Technological Pedagogical Content Knowledge ( TPACK ) in China. Journal of Educational Technology \& Society, 18(1), 158-169.

Garba, S. A., Byabazaire, Y., \& Busthami, A. H. (2015). Toward the use of 21st-century teaching-learning approaches The trend of development in Malaysian schools within the context of Asia Pacific. International Journal of Emerging Technologies in Learning, 10(4), 7279. https://doi.org/10.3991/ijet.v10i4.4717

Geng, G. (2013). Investigating the use of text messages in mobile learning. Active Learning in Higher Education, 14(1), 77-87. https://doi.org/10.1177/1469787412467122

Ghavifekr, S., Razak, A., Ghani, M., Ran, N., Meixi, Y., \& Tengyue, Z. (2014). ICT Integration in Education: Incorporation for Teaching \& Learning Improvement. Malaysian Online Journal of Educational Technology, 2(2), 24-45.
Ghavifekr, S., \& Rosdy, W. A. W. (2015). Teaching and Learning with Technology: Effectiveness of ICT Integration in Schools. International Journal of Research in Education and Science, 1(2), 175. https://doi.org/10.21890/ijres.23596

Ghavifekr, S., Kunjappan, T., \& Ramasamy, L. (2016). Teaching and Learning with ICT Tools: Issues and Challenges from Teachers' Perceptions. Malaysian Online Journal of Educational Technology, 4(2), 38-57.

Gilakjani, A. P. (2013). Factors contributing to teachers' use of computer technology in the classroom. Universal Journal of Educational Research, 1(3), 262-267. https://doi.org/10.13189/ujer.2013.010317

HakiElimu. (2016). Teachers Motivation and Job Satisfaction Research Report. Dar es Salaam.

Hennessy, S., Harrison, D., \& Wamakote, L. (2010). Teacher Factors Influencing Classroom Use of ICT in Sub-Saharan Africa. Itupale Online Journal of African Studies, 2, 39-54.

Highfield, K., De Gioia, K., \& Lane, R. (2016). Tablet Technology and Cloud Storage as Evidence of Pedagogic Development in Pre-service Teacher Education. Australasian Journal of Early Childhood, 41(4), 44-51. https://doi.org/10.1177/183693911604100406

Hong, A. H., \& Sullivan, F. R. (2013). Towards an idea-centered, principle-base design to as creation approach support learning knowledge. Educational Technology Research and Development, 57(5), 613-627. https://doi.org/10.1007/sl

Ismail, I., Azizan, S. N., \& Gunasegaran, T. (2016). Mobile learning in Malaysian universities: Are students ready? International Journal of Interactive Mobile Technologies, 10(3), 17-23. https://doi.org/10.3991/ijim.v10i3.5316

Kazoka, R., \& William, F. (2016). Secondary School Teachers' Knowledge and Practice towards the Use of ICT. Merit Research Journal of Education and Review, 4(2), 15-18. 
Kearney, M., \& Maher, D. (2019). Mobile learning in pre-service teacher education: Examining the use of professional learning networks. Australasian Journal of Educational Technology, 1(35), 135-148.

Kelly, D. P. (2015). Overcoming Barriers to Classroom Technology Integration. Educational Technolgoy, 55(2), 40-43. https://doi.org/10.1080/01425690701737481

Kihoza, P., Zlotnikova, I., Bada, J., \& Kalegele, K. (2016). Classroom ICT integration in Tanzania: Opportunities and challenges from the perspectives of TPACK and SAMR models. International Journal of Education and Development Using Information and Communication Technology, 12(1), 107-128. Retrieved https://www.learntechlib.org/d/173436/

Kim, D.-J., Kim, D., \& Choi, S.-H. (2016). How Does The Use Of Mobile Devices Affect Teachers' Perceptions On Mobile Learning? International Conferences ITS, ICEduTech and STE 2016, 297300.

Koehler, M. J., \& Mishra, P. (2009). What is

Technological Pedagogical Content Knowledge? Contemporary Issues in Technology and Teacher Education, 9(1), 60-70.

https://doi.org/10.1177/002205741319300 303

Koehler, M. J., Mishra, P., Kereluik, K., Shin, T. S., \& Graham, C. R. (2014). The Technological Pedagogical Content Knowledge

Framework. In J. M. Spector, M. D. Merrill, J. Elen, \& M. J. Bishop (Eds.), Handbook of Research on Educational Communications and Technology: Fourth Edition (pp. 1-1005). https://doi.org/10.1007/978-1-4614-3185-5

Kohnke, L. (2019). A Book Review of Mobile Learning (Oxford: Oxford University Press, 2017), 102 pp. ISBN: 978-0-19-420039-4. RELC Journal, 50(3), 497-503. https://doi.org/10.1177/0033688217748025

Lahiri, M., \& Moseley, J. L. (2018). Is Mobile Learning the Future of 21st Century Education? Educational Considerations from Various Perspectives. Educational Technology, 52(4),
3-13.

Likoko, S., Mutsotso, S., \& Nasongo, J. (2013). The Adequacy of Instructional Materials and Physical Facilities and their Effects on Quality of Teacher Preparation in Emerging Private Primary Teacher Training Colleges in Bungoma County, Kenya. International Journal of Science and Research, 2(1), 403-408.

Liu, S., Tsai, H., \& Huang, Y. (2015). Collaborative Professional Development of Mentor Teachers and Pre-Service Teachers in Relation to Technology Integration. Journal of Educational Technology \& Society, 18(3), 161-172. Retrieved from https://www.jstor.org/stable/10.2307/jeducte chsoci.18.3.161 ?seq=1\&cid=pdfreference\#references_tab_contents

Liu, P. (2016). Technology integration in elementary classrooms: Teaching practices of student teachers. Australian Journal of Teacher Education, 41(3), 87-104. https://doi.org/10.14221/ajte.2016v41n3.6

Malero, A., Ismail, A., \& Manyilizu, M. (2015). ICT Usage Readiness for Private and Public Secondary Schools in Tanzania, a Case of Dodoma Municipality. International Journal of Computer Applications, 129(3), 29-32. https://doi.org/10.5120/ijca2015906791

Mishra, P., \& Koehler, M. J. (2006). Technological Pedagogical Content Knowledge: A Framework for Teacher Knowledge. Teachers College Record, 108(6), 1017-1054. Retrieved from http://one2oneheights.pbworks.com/f/MISHR A_PUNYA.pdf

Montrieux, H., Vanderlinde, R., Schellens, T., \& De Marez, L. (2015). Teaching and learning with mobile technology: A qualitative explorative study about the introduction of tablet devices in secondary education. PLOS ONE, 10(12), 117.

https://doi.org/10.1371/journal.pone.0144008

Mwalongo, A. (2011). Teachers ' perceptions about ICT for teaching, professional development , administration and personal use Alcuin Mwalongo Dar es Salaam University College of Education , Tanzania. International Journal of 
Education and Development Using Information and Communication Technology, 7(3), 36-49.

Ndibalema, P. (2014). Teachers' attitudes towards the use of information communication technology ( ICT ) as a pedagogical tool in secondary schools in Tanzania: The case of Kondoa District. International Journal of Education and Research, 2(2), 1-16.

Ngeze, L. V. (2017). ICT Integration in Teaching and Learning in Secondary Schools in Tanzania: Readiness and Way Forward. International Journal of Information and Education Technology, 7(6), 424-427. https://doi.org/10.18178/ijiet.2017.7.6.905

Nickerson, C., Rapanta, C., \& Goby, V. P. (2017). Mobile or Not? Assessing the Instructional Value of Mobile Learning. Business and Professional Communication Quarterly, 80(2), 137-153.

https://doi.org/10.1177/2329490616663707

Okongo, R. B., Ngao, G., Rop, N. K., \& Nyongesa, W. J. (2015). Effect of Availability of Teaching and Learning Resources on the Implementation of Inclusive Education in Pre-School Centers in Nyamira North Sub-County, Nyamira County, Kenya. Journal of Education and Practice, 6(35), 132-141. Retrieved from http://ezproxy.library.yorku.ca/login?url=http: //search.proquest.com/docview/1773227117? accountid $=15182$

Oz, H. (2014). Prospective English Teachers ' Ownership And Usage Of Mobile Devices As MLearning Tools. Procedia - Social and Behavioral Sciences, 141, 1031-1041. https://doi.org/10.1016/j.sbspro.2014.05.173

Radovan, M., \& Kristl, N. (2017). Acceptance of technology and its impact on teacher's activities in virtual classroom: Integrating UTAUT and Col into a combined model. Turkish Online Journal of Educational Technology, 16(3), 11-22.

Ranasinghe, A. I., \& Leisher, D. (2009). The Benefit of Integrating Technology into the Classroom. International Mathematical Forum, 4(40),
1955-1961. Retrieved from http://www.mhikari.com/imf-password2009/37-402009/ranasingheIMF37-40-2009.pdf

Ruggiero, D., \& Mong, C. J. (2015). The teacher technology integration experience: Practice and reflection in the classroom. Journal of Information Technology Education: Research, 14, 161-178. https://doi.org/10.28945/2227

Şad, S. N., \& Göktaş, Ö. (2014). Preservice teachers' perceptions about using mobile phones and laptops in education as mobile learning tools. British Journal of Educational Technology, 45(4), 606-618. https://doi.org/10.1111/bjet.12064

Srisawasdi, N., Pondee, P., \& Bunterm, T. (2018). Preparing pre-service teachers to integrate mobile technology into science laboratory learning: an evaluation of technologyintegrated pedagogy module. International Journal of Mobile Learning and Organisation, 12(1), 1-17. https://doi.org/10.1504/IJMLO.2018.089239

URT. (2003). NATIONAL INFORMATION AND COMMUNICATIONS TECHNOLOGIES POLICY. Dar es Salaam.

URT. (2007). INFORMATION AND COMMUNICATION TECHNOLOGY (ICT) POLICY FOR BASIC EDUCATION. MINISTRY OF EDUCATION AND VOCATIONAL TRAINING (MOEVT). https://doi.org/10.1007/978-1-349-077823_161

Venkatesh, V., Morris, M. G., Davis, G. B., \& Davis, F. D. (2003). Angiogenesis induced by mast cell secretion in rat peritoneal connective tissue is a process of three phases. MIS Quarterly, $27(3), 425-478$.

Wai, C., \& Chen, J. (2015). Mobile learning : Using application Auralbook to learn aural skills. https://doi.org/10.1177/0255761414533308

Walck, P. E., Cruikshank, S. A., \& Kalyango, Y. (2015). Mobile learning: Rethinking the future of journalism practice and pedagogy. Journalism and Mass Communication Educator, 70(3), 235-250. 
https://doi.org/10.1177/1077695815600478

Yusuf, M. O. (2005). Information and communication technology and education: Analysing the Nigerian national policy for information technology. International Education Journal, 6(3), 316-321.

Zogheib, S. (2014). Factors Affecting Preservice
Teachers' Computer Use for General Purposes: Implications for Computer Training Courses. Journal of Educational Technology Systems, 43(1), 35-53. 